\title{
How Does a Staggered Board Provision Affect Corporate Strategic Change?-Evidence from China's Listed Companies
}

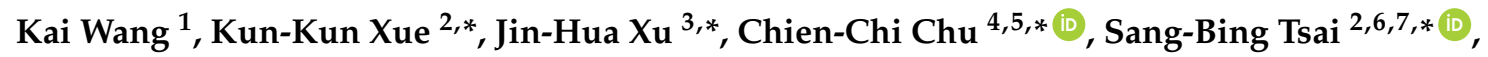 \\ He-Jun Fan ${ }^{1, *}$, Zhen-Yu Wang ${ }^{2}$ and Jiangtao Wang ${ }^{6}$ \\ 1 College of Business Administration, Capital University of Economics and Business, Beijing 100070, China; \\ wangkai@cueb.edu.cn \\ 2 China Academy of Corporate Governance, Nankai University, Tianjing 300071, China; \\ wzytjnk@mail.nankai.edu.cn \\ 3 School of Management, Guangdong University of Technology, Guangzhou 510520, China \\ 4 Department of Finance, Business School, Shantou University, Shantou 515063, China \\ 5 Research Institute for Guangdong-Taiwan Business Cooperation, Shantou University, Shantou 515063, China \\ 6 Zhongshan Institute, University of Electronic Science and Technology of China, Zhongshan 528402, China; \\ jiangtao-w@foxmail.com \\ 7 Research Center for Environment and Sustainable Development of China Civil Aviation, Civil Aviation \\ University of China, Tianjin 300300, China \\ * Correspondence: jqzhu@stu.edu.cn (C.-C.C.); sangbing@hotmail.com (S.-B.T.); kkxue8915@163.com \\ (K.-K.X.); xujh_sysu@foxmail.com (J.-H.X.); fanhj@cueb.edu.cn (H.-J.F.); Tel.: +86-760-8832-8103 (S.-B.T.)
}

Received: 20 April 2018; Accepted: 1 May 2018; Published: 3 May 2018

\begin{abstract}
As China's capital market has become more and more developed, listed companies have begun to establish some anti-takeover provisions to protect their controlling right. Existing studies have examined the consequences of the establishment of such provisions. However, few studies have explored how these provisions affect corporate strategic change. Based on agency theory and prospect theory, this paper proposes two channels through which one of the anti-takeover provisions, staggered board provision, impacts strategic change. Using the data of China's listed companies which issue A-shares in Shenzhen and Shanghai stock exchanges from 2007 to 2014, these two channels are tested. We find that the existence of a staggered board provision negatively affects the extent of strategic change. In addition, if governance mechanisms restrict directors' power, the relationship between staggered board provision and strategic change will be weakened, which supports the agency theory. If the listed company is faced with a more dynamic external environment, the relationship between staggered board provision and strategic change will be stronger, which supports the prospect theory. These results are robust after we use a different method to measure strategic change. Our conclusions not only enrich literature about strategic change and anti-takeover provisions, but also are helpful for improving corporate governance in China and other developing countries.
\end{abstract}

Keywords: staggered board provision; strategic change; corporate governance; environment dynamism; anti-takeover provision; Ethics in finance; sustainable finance

\section{Introduction}

With the development of China's capital market, merger and acquisitions (M\&As) have become an important way of large companies to grow. Accordingly, more and more companies become the targets of takeovers. In addition, with the acceleration of globalization, the entry of foreign capital makes takeovers more common. Although takeover plays an important role in monitoring managers' 
behavior, listed companies try to take some actions to defend it. That is why a lot of China's listed companies have begun to establish anti-takeover provisions since the milestone event.

There have already been a lot of studies focusing on anti-takeover provisions. On the one hand, some scholars have analyzed what factors affect the establishment of these provisions [1,2]. On the other hand, some scholars have examined the consequences of the establishment of anti-takeover provisions [3,4]. The second stream of studies is abundant. Deangelo and Rice (1983) divided these studies into two groups [5]. One group focuses on how the establishment of anti-takeover provisions affects management entrenchment behaviors, while the other group focuses on how the provisions affect M\&A deals. However, few studies have explored the relationship between anti-takeover provisions and corporate strategic change. Considering the important role of strategic change in gaining sustainable competitive advantage [6], this paper tries to identify the channels through which an anti-takeover provision affects corporate strategic change and empirically test them.

There are many kinds of anti-takeover provisions, such as super-majority provision, cumulative voting provision, and staggered board provision and so on. Considering the first two kinds of provisions are so popular among China's listed companies $(92.5 \%$ and $90.5 \%$ of China's listed companies have already established these two provisions, respectively), we focus on staggered board provision in this paper.

A staggered board provision can make some board members stay a long time to serve on the board. Based on agency theory, directors who have served longer on the board are more powerful than those who served shorter [7]. They can use their power to satisfy their own interests, and ignore the company's sustainable development, leading to their paying less attention to strategic change. In addition, based on prospect theory, directors cherish their gains very much, in terms of salary and reputation. Directors with longer tenure will not take a strategic change at the risk of losing their reputation, since strategic change may lead to failure [6]. Combining these two theories together, we estimate that the existence of staggered board provision will decrease the extent of strategic change. Furthermore, we introduce two moderating effects for each channel, respectively. We argue that the restriction of governance mechanisms on board members' power weakens the relationship between staggered board provision and strategic change, which is consistent with agency theory. Additionally, the environment dynamism also has the opposite moderating effect, which is consistent with prospect theory. By analyzing the data of China's listed companies, our hypotheses are all testified.

Through analyzing how the establishment of a staggered board provision affects corporate strategic change, this paper contributes to the literature in three ways. First, existing studies have examined the impact of some corporate governance mechanisms on strategic change, such as shareholder structure, board of directors, CEO turnover and so on $[8,9]$. In this paper, we focus on one emerging governance means, named staggered board provision, and analyze how it affects strategic change, which enriches the literature on the relationship between corporate governance and strategic change. Second, we contribute to the literature on anti-takeover provisions by integrating agency theory and prospect theory to analyze the consequences of one specific provision. By doing this, the roles of anti-takeover provisions become more clear. Third, to test the channels through which staggered board provision affect strategic change, we examine two moderating effects. After examining these moderating effects, we find that different governance mechanisms interact with each other, which enriches studies on corporate governance.

The remaining parts are structured as follows: Section 2 reviews literature about determinants of strategic change and different roles of anti-takeover provisions. Section 3 proposes three hypotheses on the relationship between staggered board provision and strategic change based on agency theory and prospect theory. Section 4 introduces our research design, consisting of sample selection and variable definition. The empirical results and robustness tests are demonstrated in Section 5. Our conclusions are presented in Section 6. 


\section{Literature Review}

To highlight the theoretical contribution of this paper, we review existing studies on strategic change and anti-takeover provisions in this section.

\subsection{The Determinants of Strategic Change}

Scholars have identified many factors which can affect the extent of strategic change. Some scholars focus on firms' external environment, and examine how the dynamism of external environment affects strategic change. For example, Meyer et al. (1990) analyze how hospitals change their strategy in both industry level and organization level because of the increasing competition pressure [10]. Kelly and Amburgey (1991) focus on aviation industry, and analyze how firms in this industry change their strategy since deregulation. They find that the change of external environment does not necessarily lead to strategic change, and it will depend on firms' age, size and whether it has changed its strategy before [11]. Haveman (1992) analyzes how the change of external environment affects firms' strategic change in banking industry. They find that, through changing strategy when the environment changes, firms' performance can be increased. In addition, firms can benefit more if the new business is more related to their original business [12]. By comparing two banks, Fox-Wolfgramm et al. (1998) find that the bank with an organization identity image which matches the change of environment more is more likely to make successful strategic change [13]. These studies show that external environment plays an important role in the decision of strategic change.

However, other scholars focus on firms' internal governance structure and governance mechanisms, and examine how corporate governance affects strategic change. For instance, Finkelstein and Hambrick (1990) find that, if a firm has a CEO with long tenure, it is less likely to make strategic change. Furthermore, CEO's discretion can strengthen the relationship between CEO tenure and strategic change [8]. Using a sample consisting of hospitals, Goodstein and Boeker (1991) find that ownership structure and board of directors have both independent and interactive effects on strategic change [9]. Wiersema and Bantel (1992) examine the impact of some governance variables on the extent of strategic change, they find that, if firms have top management teams with lower average age, shorter firm tenure, longer team tenure, higher average educational level, higher educational background heterogeneity, and higher average academic training level, they will be more likely to make strategic change [14]. Boeker (1997) examines how performance and top management teams (TMT) characteristics affect strategic change. They find that firms with lower performance, shorter CEO and TMT tenure, and higher TMT diversity are more likely to change their strategies. In addition, poorer performance can strengthen the impact of TMT characteristics on strategic change [15]. Haynes and Hillman (2010) empirically test the impact of board social capital on strategic change, and find that there is difference between the impact of social capital's width and that of social capital's depth. Specifically, the wider the board social capital, the larger extent of strategic change, while the deeper the board social capital, the lower extent of strategic change [16]. Quigley and Hambrick (2012) pay their attention to a phenomenon, which is the former CEO continues to stay in the firm as board chairman. They find that this kind of leadership structure can limit the new CEO's power of strategic change [17].

Overall, existing studies have identified many factors which affect strategic change. These studies provide the foundation for our analysis of the relationship between a staggered board provision and strategic change. At the same time, our analysis can enrich this stream of literature.

\subsection{The Roles of Anti-Takeover Provisions}

Some scholars argue that anti-takeover provisions can affect firms' behavior through two channels: one is management entrenchment hypothesis; the other is bargaining benefits hypothesis [5]. The first hypothesis is that managers introduce anti-takeover provisions to protect their own positions and other interests, while the second one is that relying on these provisions, the target firm can 
benefit more during the process of M\&A negotiation. Existing studies empirically test these two hypotheses, respectively.

Some studies support management entrenchment hypothesis. For example, Faleye (2007) analyzes the relationship between a staggered board provision and executive compensation and CEO turnover, and finds that the existence of this provision can decrease board monitoring efficiency, which harms performance [3]. By constructing an index to measure the extent of anti-takeover, Bebchuk et al. (2009) examine the role of anti-takeover provisions, and find that the higher score in their index, the lower the performance [18]. Ahn and Shrestha (2013) find that in firms with higher monitoring cost, the existence of staggered board provisions can harm performance, which is consistent with entrenchment hypothesis [19]. However, other scholars find different results. For instance, Danielson and Karpoff (2006) find that firms which have introduced poison pill provisions do not always have negative performance. In contrast, these firms' performance will be improved in five years [20]. Duru et al. (2013) examine how a firm's transparency affects the relationship between a staggered board provision and performance, and find that this provision can improve performance in firms with lower transparency [21].

Also, there are some studies that examine bargaining benefits hypothesis by analyzing the impact of anti-takeover provisions on M\&A profitability and premium. The findings of some studies are consistent with this hypothesis. For example, using a sample consisting of IPO firms, Field and Karpoff (2002) find that anti-takeover provisions can decrease firms' profitability of being acquired after IPO [2]. Heron and Lie (2006) find that firms with poison pill provisions usually get higher M\&A premium [22]. Bates et al. (2008) compare the profitability of being acquired between firms with a staggered board provision and firms without that, and find that the former firms are less likely to be acquired [23]. Chen et al. (2015) examine the roles of a cumulative voting provision of China's family listed companies, and find that firms with such a provision are less likely to be targets for M\&A [24]. However, some other studies do not support this bargaining benefits hypothesis. For instance, Bebchuk et al. (2002) find that there is no significant difference in M\&A premium between firms with a staggered board provision and firms without that [25].

Overall, existing studies on anti-takeover provisions have examined how these provisions affect firms' behavior from different perspectives. However, there are few studies focusing on how these provisions affect strategic change. In this paper, we try to enrich this stream of literature by empirically testing the channels through which a staggered board provision affects the extent of strategic change.

\section{Theory and Hypotheses Development}

In this section, we develop three hypotheses on the relationship between staggered board provision and strategic change based on agency theory and prospect theory.

\subsection{The Impact of Establishment of a Staggered Board Provision on Strategic Change}

According to agency theory, directors who serve longer in the listed company will have more power and use their power to pursue their own short-term interests, instead of long-term interests of the company [7]. Some studies on strategic change have provided empirical evidence for this argument. As strategic change needs a huge amount of efforts [26], directors with longer tenure are unwilling to waste energy on such activities which are helpful for the companies' long-term development $[8,14,17]$. If there is a staggered board provision, some directors will stay longer on the board, which may prevent the strategic change.

In addition, according to prospect theory, most people prefer fixed earnings rather than potential income; besides, most people are loss averters [27]. For directors who sit on the board, they not only worry about losing their salary, but also are afraid of losing their reputation. As strategic change may lead to a failure [6], directors will not take such actions at the risk of their reputation. Although Kahneman and Tversky (1979) argue that the sensitivity to loss aversion and a preference for gains wear off as outcomes approach the extremes of either the domain of losses or the domain 
of gains [27], the consequences of strategic change are uncertainty [6], and they cannot reach the two extremes. So generally, directors are risk averse in terms of strategic change. Sliwka's (2007) findings support this argument. Using a method of modeling, they find that managers don't want to make strategic change concerning their reputation, even if the financial information indicates that strategic change is necessary [28]. The longer a director stays on the board, the more he or she will care about his or her reputation. Based on this, the existence of a staggered board provision will lead to a lower probability of strategic change.

Combining these two theories together, we propose our first hypothesis:

Hypothesis 1 (H1): If there is a staggered board provision, the extent of corporate strategic change will be less.

\subsection{The Moderating Effect of Governance Mechanisms Based on Agency Theory}

In essence, corporate governance refers to some mechanisms used by corporate stakeholders to restrict each other [29]. In the case of the controlling right contest between Baoneng Group and Vanke Co., Ltd., in China in 2015, we can see the mutual restriction between shareholders and directors. Following this logic, shareholders can use some governance mechanisms to restrict directors' power. Specifically, if the share ratio of the first shareholder is larger, directors will have lower power [7]. Also, in China's context, restriction from shareholders to directors is larger in state-owned enterprises (SOEs) than in private firms, since government as the largest shareholder usually intervenes in the decision-making of an SOE [30]. Based on the above analysis, we propose our hypotheses on the moderating effect of shareholders' governance.

Hypothesis 2a (H2a): The higher the largest shareholder's share ratio, the less significant the relationship between a staggered board provision and the extent of strategic change.

Hypothesis $\mathbf{2} \mathbf{b}(\mathbf{H} \mathbf{2} \mathbf{b})$ : The relationship between a staggered board provision and the extent of strategic change is less significant in an SOE than in a private firm.

\subsection{The Moderating Effect of Environment Dynamism Based on Prospect Theory}

Environment dynamism is a concept to measure the dynamic changes of firms' external environment [31], especially in China's transitional context, firms' external environment changes rapidly [32,33]. Some scholars have analyzed how environment dynamism affects firms' decision-making; for example, York and Venkataraman (2010) found that if the environment is dynamic, firms will not try green product innovation. They explained this phenomenon in such a way that firms are afraid of the failure of product innovation, since the information provided by the environment is not enough [34]. Following the same logic, we argue that if the external environment is dynamic, directors will be more worried about the failure of strategic change, which can damage their reputation. Also, according to Lopes (1986), people's desire for security (risk-averse) or potential (risk-seeking) depends on a situational variable, aspiration level [35]. When the environment dynamism is higher, directors will have a lower aspiration level (strategic change may be not successful), thus have more desire for security. Based on the above analysis, we propose our hypothesis on the moderating effect of environment dynamism.

Hypothesis $\mathbf{3}$ (H3): The higher the environment dynamism, the stronger the relationship between a staggered board provision and the extent of strategic change.

Figure 1 shows our theoretical model consisting of the above hypotheses. Words in square frames stand for variables, while words in oval frames represent theories to explain the relationship between variables. 


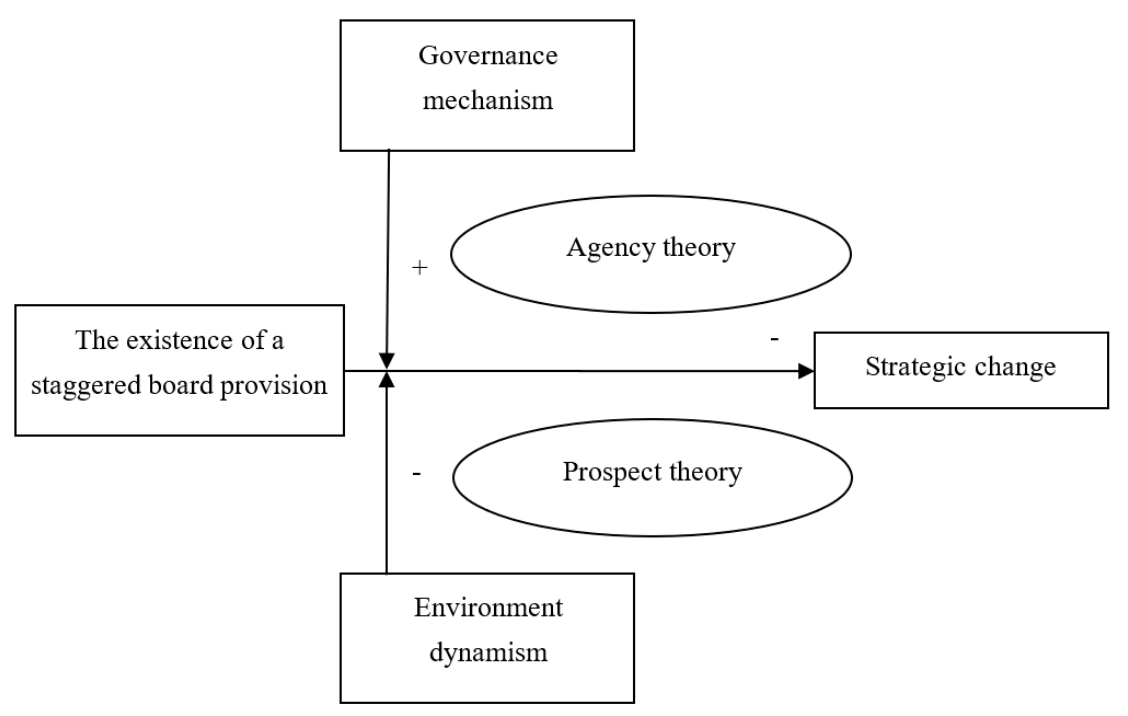

Figure 1. Theoretical model.

\section{Research Design}

\subsection{Sample Selection}

Our original sample consists of listed companies which issued A-shares in Shenzhen and Shanghai stock exchanges from 2007 to 2014 . The reason why we choose this sample period is that the staggered board provision variable is lagged for one year to deal with endogenous problems (that is, strategic change may affect the introduction of a staggered board provision, which disturbs our interpretation of the results), and data on this variable has been available since 2006. In 2006, China's new corporation law enhanced the importance of the articles of association in corporate governance. Accordingly, China's listed companies began to design many detailed provisions in their articles of association, including anti-takeover provisions. After excluding companies which (1) receive special treatment; (2) belong to financial industry and (3) have missing data, our final sample includes 9972 firm-years. Data about staggered board provisions is hand-collected from companies' articles of associations, while other variables are collected from CSMAR database.

\subsection{Measurements}

The independent variable is strategic change. We measure it referring to Zhang and Rajagopalan (2010) [6]. Specifically, we choose six financial indicators, which are advertisement expenditure, R\&D investment, rate of fixed assets renewal, overhead rate, inventory level and financial leverage to measure firms' strategic change. Firstly, we compute the difference between year $\mathrm{t}$ and year $\mathrm{t}-1$ in every indicator. Secondly, we adjust these difference values using the industry medians. Thirdly, we take the absolute values of these industry-adjusted differences and standardize them. The mean of these standardized values is our extent of strategic change (sc).

Our dependent variable is a dummy variable (sbp), which equals 1 if there is a staggered board provision in the company's articles of association. Otherwise, it equals 0.

To test the moderating effect of shareholders' governance mechanisms, we introduce a moderate variable, which is the share percentage of the largest shareholder (no1share). Also, we divide the sample into two subsamples, based on whether a company is state-owned or not, and compare the roles of staggered board provisions between these two subsamples. To test the moderating effect of external environment, we introduce another moderate variable, which is environment dynamism (ed). According to Dess and Beard (1984) [36], we use the revenue in year $\mathrm{t}$, year $\mathrm{t}-1$, year $\mathrm{t}-2$, year $\mathrm{t}-3$, and year $\mathrm{t}-4$ as values of dependent variable, and 5, 4, 3, 2, and 1 as values of independent variable 
to conduct OLS regression [37-43]. The standard error of regression coefficient divided by the mean value of revenue in these five years is our environment dynamism variable [44-50].

According to existing studies [6,8], some variables are controlled, including (1) firm size (size), measured by the natural logarithm of total assets; (2) firm's profitability (roa), measured by return on assets; (3) revenue growth (growth), which equals the difference of revenue between year $t$ and year $\mathrm{t}-1$ divided by that in year $\mathrm{t}-1$; (4) firm age (age), measured by the observed year minus the year in which the firm was listed. Also, we control the moderate variables, including the share percentage of the largest shareholder (no1share), whether the company is state-owned (state) and environment dynamism (ed). That is because existing studies have shown that ownership structure [9] and external environment [12] can affect the extent of strategic change. Lastly, we control the industry effects and year effects.

\section{Empirical Results}

\subsection{Descriptive Statistics}

Table 1 shows the descriptive statistics of variables in our regression models. In order to mitigate the influence of outliers and data errors, we winsorize all continuous variables at the $1 \%$ and $99 \%$ levels. The mean value of sc is -0.012 , and it has a large SD, which indicates that the extent of strategic change varies from companies in our sample. These results are similar to the findings of other studies using samples from U.S. [6,15]. Only $4.3 \%$ of companies in our sample have established the staggered board provisions, which indicates that this kind of anti-takeover provision needs to be further generalized. In addition, the mean value of no1share is $35.9 \%$, which supports the argument that Type II agency problems are serious among China's listed companies [51]. State-owned companies occupy $59.5 \%$ in our sample. Also, it shows that different companies are faced with different extent of environment dynamism.

Table 1. Descriptive statistics.

\begin{tabular}{cccccc}
\hline Variables & Obs & Mean & SD & Min & Max \\
\hline sc & 9972 & -0.012 & 0.190 & -0.771 & 1.028 \\
sbp & 9972 & 0.043 & 0.204 & 0 & 1 \\
size & 9972 & 22.058 & 1.214 & 19.520 & 22.519 \\
roa & 9972 & 0.036 & 0.053 & -0.220 & 0.194 \\
growth & 9972 & 0.174 & 0.418 & -0.645 & 2.606 \\
age & 9972 & 11.323 & 4.750 & 3 & 24 \\
no1share & 9972 & 0.359 & 0.153 & 0.089 & 0.750 \\
state & 9972 & 0.595 & 0.491 & 0 & 1 \\
ed & 9972 & 0.003 & 0.003 & 0.000 & 0.022 \\
\hline
\end{tabular}

sc: strategic change; sbp: staggered board provision dummy variable; size: firm size; roa: return on assets; growth: revenue growth; age: firm age; no1share: share percentage of largest shareholder; state: whether company is state-owned; ed: environment dynamism.

\subsection{Correlation Analysis}

A correlation coefficient matrix between all the variables is showed in Table 2. As we can see in Table 2, the correlation coefficient between sc and sbp has a negative sign, but it is not statistically significant. How a staggered board provision affects the extent of strategic change needs to be further analyzed through regression analysis. The correlation coefficient between sc and roa is negative and statistically significant at the one percent level, so is the coefficient between sc and growth. These results indicate that companies with good performance and good growth opportunity are less likely to change their strategies, which is consistent with existing studies [15]. The largest correlation coefficient between explanatory variables and control variables in Table 2 is 0.298 , which indicates that the collinearity problem is not substantial. 
Table 2. Correlation analysis.

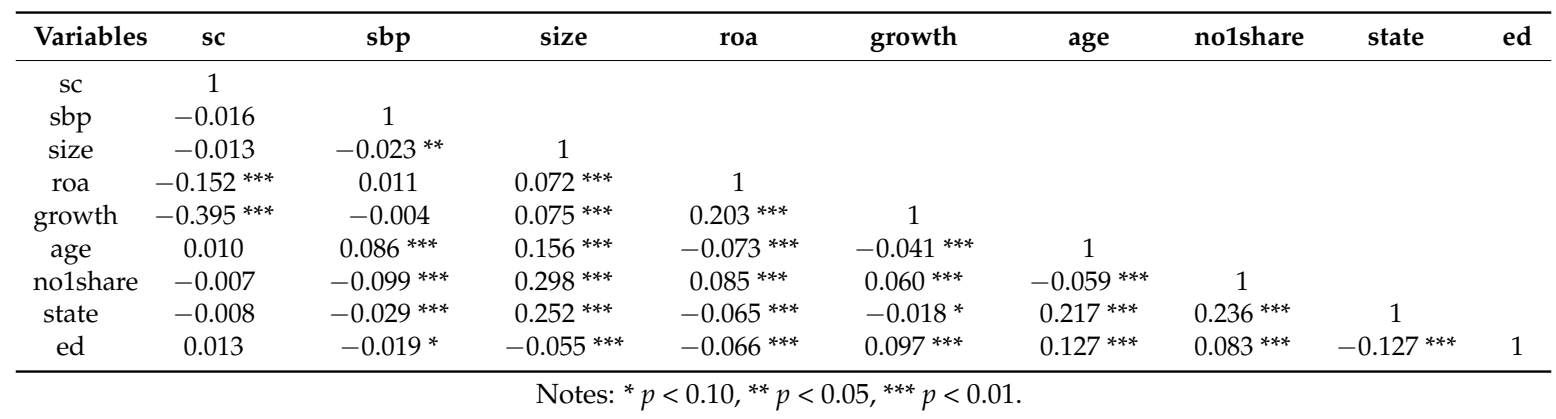

\subsection{Regression Analysis}

Table 3 reports the regression results. Model 1 is a base model, which only includes control variables. As indicated in Model 1, the coefficient of size is positive and statistically significant in one percent level, which is consistent with Finkelstein and Hambrick's (1990) results [8]. The fact that larger firms are more likely to make strategic change may be because they have more abundant resources. Both the coefficients of roa and growth are negative and statistically significant at the one percent level, which is consistent with results in Boeker (1997) [15]. Also, the coefficient of ed is consistent with Haveman (1992) [12], which shows that firms change their strategy when their external environment changes. In addition, the coefficient of state shows that compared with SOEs, non-SOEs are more likely to make strategic change.

Table 3. Regression analysis.

\begin{tabular}{|c|c|c|c|c|c|c|}
\hline Variables & Model 1 & Model 2 & Model 3 & Model 5 & Model 6 & Model 7 \\
\hline & & & & state $=1$ & state $=0$ & \\
\hline sbp & & $\begin{array}{c}-0.013 \text { * } \\
(0.008)\end{array}$ & $\begin{array}{c}-0.013 \text { * } \\
(0.008)\end{array}$ & $\begin{array}{c}0.007 \\
(0.008)\end{array}$ & $\begin{array}{c}-0.035^{* * *} \\
(0.012)\end{array}$ & $\begin{array}{l}-0.002 \\
(0.009)\end{array}$ \\
\hline $\begin{array}{l}\text { no1share * } \\
\text { sbp }\end{array}$ & & & $\begin{array}{c}0.010^{* * *} \\
(0.003)\end{array}$ & & & \\
\hline $\mathrm{ed}^{*} \mathrm{sbp}$ & & & & & & $\begin{array}{c}-3.967^{* *} \\
(1.946)\end{array}$ \\
\hline size & $\begin{array}{c}0.005^{* * *} \\
(0.002)\end{array}$ & $\begin{array}{c}0.005^{* * *} \\
(0.002)\end{array}$ & $\begin{array}{c}0.006^{* * *} \\
(0.002)\end{array}$ & $\begin{array}{c}0.005^{* * *} \\
(0.002)\end{array}$ & $\begin{array}{l}0.007^{* *} \\
(0.003)\end{array}$ & $\begin{array}{c}0.005^{* * *} \\
(0.002)\end{array}$ \\
\hline roa & $\begin{array}{c}-0.283^{* * *} \\
(0.048)\end{array}$ & $\begin{array}{c}-0.282^{* * *} \\
(0.048)\end{array}$ & $\begin{array}{c}-0.627^{* * *} \\
(0.137)\end{array}$ & $\begin{array}{c}-0.320 * * * \\
(0.061)\end{array}$ & $\begin{array}{c}-0.235^{* * *} \\
(0.076)\end{array}$ & $\begin{array}{c}-0.282^{* * *} \\
(0.048)\end{array}$ \\
\hline growth & $\begin{array}{c}-0.181^{* * *} \\
(0.011)\end{array}$ & $\begin{array}{c}-0.181^{* * *} \\
(0.011)\end{array}$ & $\begin{array}{c}-0.181^{* * *} \\
(0.011)\end{array}$ & $\begin{array}{c}-0.152^{* * *} \\
(0.014)\end{array}$ & $\begin{array}{c}-0.215^{* * *} \\
(0.017)\end{array}$ & $\begin{array}{c}-0.181 \text { *** } \\
(0.011)\end{array}$ \\
\hline age & $\begin{array}{l}-0.001 \\
(0.000) \\
\end{array}$ & $\begin{array}{c}-0.001 \\
(0.000) \\
\end{array}$ & $\begin{array}{c}-0.001 \\
(0.000) \\
\end{array}$ & $\begin{array}{l}-0.001 \\
(0.000) \\
\end{array}$ & $\begin{array}{l}-0.000 \\
(0.001) \\
\end{array}$ & $\begin{array}{l}-0.001 \\
(0.000) \\
\end{array}$ \\
\hline no1share & $\begin{array}{c}0.017 \\
(0.012)\end{array}$ & $\begin{array}{c}0.015 \\
(0.012)\end{array}$ & $\begin{array}{l}-0.024 \\
(0.018)\end{array}$ & $\begin{array}{c}0.019 \\
(0.013)\end{array}$ & $\begin{array}{c}0.013 \\
(0.024)\end{array}$ & $\begin{array}{c}0.017 \\
(0.012)\end{array}$ \\
\hline state & $\begin{array}{c}-0.013^{* * *} \\
(0.004)\end{array}$ & $\begin{array}{c}-0.013^{* * *} \\
(0.004)\end{array}$ & $\begin{array}{c}-0.012^{* * *} \\
(0.004)\end{array}$ & & & $\begin{array}{c}-0.013^{* * *} \\
(0.004)\end{array}$ \\
\hline ed & $\begin{array}{l}1.680 * * \\
(0.757)\end{array}$ & $\begin{array}{l}1.674^{* *} \\
(0.755)\end{array}$ & $\begin{array}{l}1.662^{* *} \\
(0.755)\end{array}$ & $\begin{array}{c}0.575 \\
(0.940)\end{array}$ & $\begin{array}{l}2.432 * * \\
(1.192)\end{array}$ & $\begin{array}{l}1.865^{* *} \\
(0.779)\end{array}$ \\
\hline
\end{tabular}


Table 3. Cont.

\begin{tabular}{ccccccc}
\hline Industry & Controlled & Controlled & Controlled & Controlled & Controlled & Controlled \\
\hline Year & Controlled & Controlled & Controlled & Controlled & Controlled & Controlled \\
\hline \multirow{2}{*}{ cons } & $-0.083^{* *}$ & $-0.083^{* *}$ & $-0.079^{* *}$ & $-0.083^{* *}$ & $-0.121^{*}$ & $-0.085^{* *}$ \\
\hline Obs & $(0.033)$ & $(0.033)$ & $(0.033)$ & $(0.036)$ & $(0.064)$ & $(0.033)$ \\
\hline$F$-value & 9972 & 9972 & 9972 & 5938 & 4034 & 9972 \\
\hline $\mathrm{R}^{2}$ & $15.92^{* * *}$ & $15.43^{* * *}$ & $15.13^{* * *}$ & $10.19^{* * *}$ & $9.24^{* * *}$ & $14.91^{* * *}$ \\
\hline \multicolumn{2}{c}{ Notes: ${ }^{*} p<0.10,^{* *} p<0.05^{* * *} p<0.01$. Robust standard errors clustered in firm level are in parentheses. }
\end{tabular}

Our independent variable, sbp, is added into Model 2 based on Model 1. As we can see in Model 2, the existence of a staggered board provision and the extent of strategic change is negatively related ( $\beta=-0.013, p<0.10)$, which indicates that the existence of a staggered board provision decreases the extent of strategic change. These results support our hypothesis 1 .

Model 3 adds an interaction term between the share percentage of the largest shareholder and the existence of a staggered board provision to examine Hypothesis 2a. As indicated in Model 3, the coefficient of the interaction term is positive and significantly significant $(\beta=0.010, p<0.01$ ), which is consistent with our hypothesis that the largest shareholder's share percentage negatively moderates the relationship between a staggered board provision and the extent of strategic change. In addition, we examine our Hypothesis $2 \mathrm{~b}$ through comparing the coefficients of sbp between Model 5 and Model 6. As indicated, the coefficient in Model 5 is positive and not statistically significant, while the coefficient in Model 6 is negative and statistically significant at the one percent level. These results show that the role of a staggered board provision in determining strategic change is restricted in an SOE; this is because of the autonomy of the board of directors in SOEs is lower due to the existence of government intervention [30]. Our Hypothesis $2 b$ is supported.

To test Hypothesis 3, we add an interaction term between environment dynamism and the existence of a staggered board provision in Model 7. As we can see in Model 7, the coefficient of the interaction term is negative and statistically significant $(\beta=-3.967, p<0.05)$, which is consistent with our hypothesis that environment dynamism strengthens the relationship between the existence of a staggered board provision and the extent of strategic change.

\subsection{Robustness Tests}

When measuring the strategic change variable, we use six financial indicators. Three of these six indicators (advertisement expenditure, R\&D investment, and inventory level) have missing data, and we replace the missing data with zero value. In this section, we calculate strategic change again using another way proposed by Haynes and Hillman (2010) [16], which excludes these three variables with missing data, and only the other three are included in the final variable. We use this new strategic change variable to run all the regressions again; the results are showed in Table 4. As indicated in Table 4 , our conclusions are robust. 
Table 4. Robustness tests.

\begin{tabular}{|c|c|c|c|c|c|c|}
\hline Variables & Model 1 & Model 2 & Model 3 & Model 5 & Model 6 & Model 7 \\
\hline & & & & state $=1$ & state $=0$ & \\
\hline $\mathrm{sbp}$ & & $\begin{array}{l}-0.004 \\
(0.004)\end{array}$ & $\begin{array}{l}-0.005 \\
(0.004)\end{array}$ & $\begin{array}{c}0.003 \\
(0.004)\end{array}$ & $\begin{array}{c}-0.013 * \\
(0.007)\end{array}$ & $\begin{array}{c}0.004 \\
(0.005)\end{array}$ \\
\hline $\begin{array}{c}\text { no1share * } \\
\text { sbp }\end{array}$ & & & $\begin{array}{l}0.006^{* * *} \\
(0.002)\end{array}$ & & & \\
\hline$e^{*} \mathrm{sbp}$ & & & & & & $\begin{array}{c}-3.218^{* * *} \\
(1.237)\end{array}$ \\
\hline size & $\begin{array}{l}0.004^{* * *} \\
(0.001)\end{array}$ & $\begin{array}{l}0.004^{* * *} \\
(0.001)\end{array}$ & $\begin{array}{c}0.004^{* * *} \\
(0.001)\end{array}$ & $\begin{array}{c}0.004^{* * *} \\
(0.001)\end{array}$ & $\begin{array}{l}0.004^{* *} \\
(0.001)\end{array}$ & $\begin{array}{c}0.004^{* * *} \\
(0.001)\end{array}$ \\
\hline roa & $\begin{array}{c}-0.340^{* * *} \\
(0.031)\end{array}$ & $\begin{array}{c}-0.340 * * * \\
(0.031)\end{array}$ & $\begin{array}{c}-0.536^{* * *} \\
(0.075)\end{array}$ & $\begin{array}{c}-0.375^{* * *} \\
(0.042)\end{array}$ & $\begin{array}{c}-0.291^{* * *} \\
(0.044)\end{array}$ & $\begin{array}{c}-0.340^{* * *} \\
(0.031)\end{array}$ \\
\hline growth & $\begin{array}{c}-0.077^{* * *} \\
(0.005)\end{array}$ & $\begin{array}{c}-0.076^{* * *} \\
(0.005)\end{array}$ & $\begin{array}{c}-0.077^{* * *} \\
(0.005)\end{array}$ & $\begin{array}{c}-0.060^{* * *} \\
(0.006)\end{array}$ & $\begin{array}{c}-0.097^{* * *} \\
(0.007)\end{array}$ & $\begin{array}{c}-0.077^{* * * *} \\
(0.005)\end{array}$ \\
\hline age & $\begin{array}{c}-0.001^{* * *} \\
(0.000)\end{array}$ & $\begin{array}{c}-0.001 * * * \\
(0.000)\end{array}$ & $\begin{array}{c}-0.001^{* * *} \\
(0.000)\end{array}$ & $\begin{array}{l}-0.000 \\
(0.000)\end{array}$ & $\begin{array}{c}-0.001^{* * *} \\
(0.000)\end{array}$ & $\begin{array}{c}-0.001^{* * * *} \\
(0.000)\end{array}$ \\
\hline no1share & $\begin{array}{c}0.009 \\
(0.006)\end{array}$ & $\begin{array}{c}0.009 \\
(0.006)\end{array}$ & $\begin{array}{l}-0.014 \\
(0.010)\end{array}$ & $\begin{array}{l}0.012 * \\
(0.007)\end{array}$ & $\begin{array}{c}0.004 \\
(0.011)\end{array}$ & $\begin{array}{l}0.010 * \\
(0.006)\end{array}$ \\
\hline state & $\begin{array}{c}-0.009 * * * \\
(0.002)\end{array}$ & $\begin{array}{c}-0.009 * * * \\
(0.002)\end{array}$ & $\begin{array}{c}-0.009 * * * \\
(0.002)\end{array}$ & & & $\begin{array}{c}-0.009^{* * *} \\
(0.002)\end{array}$ \\
\hline ed & $\begin{array}{l}0.937 * * \\
(0.393)\end{array}$ & $\begin{array}{l}0.935 * * \\
(0.392)\end{array}$ & $\begin{array}{l}0.928 * * \\
(0.388)\end{array}$ & $\begin{array}{c}0.404 \\
(0.486)\end{array}$ & $\begin{array}{l}1.350 * * \\
(0.627)\end{array}$ & $\begin{array}{c}1.090^{* * *} \\
(0.404)\end{array}$ \\
\hline Industry & Controlled & Controlled & Controlled & Controlled & Controlled & Controlled \\
\hline Year & Controlled & Controlled & Controlled & Controlled & Controlled & Controlled \\
\hline _cons & $\begin{array}{c}-0.057^{* * *} \\
(0.017)\end{array}$ & $\begin{array}{c}-0.057^{* * *} \\
(0.017)\end{array}$ & $\begin{array}{c}-0.055^{* * *} \\
(0.017)\end{array}$ & $\begin{array}{c}-0.069 * * * \\
(0.019)\end{array}$ & $\begin{array}{c}-0.056 * \\
(0.031)\end{array}$ & $\begin{array}{c}-0.058^{* * *} \\
(0.017)\end{array}$ \\
\hline Obs & 9972 & 9972 & 9972 & 5938 & 4034 & 9972 \\
\hline$F$-value & $22.90 * * *$ & $22.02 * * *$ & $21.45^{* * *}$ & $12.19^{* * *}$ & $12.47^{* * *}$ & $21.14^{* * *}$ \\
\hline $\mathrm{R}^{2}$ & 0.196 & 0.196 & 0.198 & 0.166 & 0.242 & 0.196 \\
\hline
\end{tabular}

\section{Conclusions}

Inspired by existing studies on anti-takeover provisions, this paper proposes two channels through which a staggered board provision affects the extent of corporate strategic change based on agency theory and prospect theory, respectively. Using a sample consisting of China's listed companies from 2007 to 2014, we empirically test these two channels. Our robust empirical findings are as follows. First, the existence of a staggered board provision decreases the extent of strategic change. Second, shareholders' restriction on directors through governance mechanisms can weaken the role of a staggered board provision in determining strategic change. Third, external environment dynamism can strengthen the relationship between a staggered board provision and the extent of strategic change.

Our conclusions have practical implications for listed companies in mature markets for corporate control. For example, listed companies should notice that anti-takeover provisions may have a negative impact on corporate sustainable development, such as restricting strategic change, even though they belong to incentive mechanisms for directors and top managers. Also, after establishing the anti-takeover provisions, listed companies should pay attention to the interaction between 
these provisions and other governance mechanisms, and identify whether they are complementary, or substitutional.

Although this paper contributes literature about anti-takeover provisions and strategic change, there exist some limitations. For instance, in business practice, small and medium companies with little historical and business background but with some innovation prospectives are the most likely victims of the large corporations that chose to grow via merges and acquisitions. According to this, investigating defensive strategies of small and medium innovative enterprises against large and mature corporations is necessary in future studies. Because the data on SMEs is not easy to obtain through open sources, survey questionnaire method and case study will be more suitable. Also, we only focus on how the introduction of a staggered board provision affects the extent of strategic change. The relationship between anti-takeover provisions and other strategic behaviors (micro-level) can be explored in the future, as well as how the introduction of these provisions affects the price indices in financial markets (macro-level) [52]. In addition, there are still few studies examining the antecedents of anti-takeover provisions [1,2]. It is necessary to analyze what affects the introduction of these provisions in the future.

Author Contributions: Writing: K.W., K.-K.X., J.-H.X.; Providing idea and data: C.-C.C., S.-B.T., H.-J.F., Z.-Y.W.; Providing revised advice: S.-B.T., C.-C.C., J.W.

Acknowledgments: This research was supported by the National Natural Science Foundation of China (Grant Number: 71702114; 71572085; 71702036), Zhongshan City Science and Technology Bureau Project (No. 2017B1015), the Provincial Natural Science Foundation of Guangdong (No. 2015A030310271 and 2015A030313679) and the Institute of Guangdong and Taiwan of Shantou University for their financial support.

Conflicts of Interest: The authors declare no conflict of interest.

\section{References}

1. Davis, G.F. Agents without principles? The spread of the poison pill through the intercorporate network. Adm. Sci. Q. 1991, 36, 583-613. [CrossRef]

2. Field, L.C.; Karpoff, J.M. Takeover defenses of IPO firms. J. Financ. 2002, 57, 1857-1889. [CrossRef]

3. Faleye, O. Classified boards, firm value, and managerial entrenchment. J. Financ. Econ. 2007, 83, 501-529. [CrossRef]

4. Sokolyk, T. The effects of antitakeover provisions on acquisition targets. J. Corp. Financ. 2011, 17, 612-627. [CrossRef]

5. Deangelo, H.; Rice, E.M. Antitakeover charter amendments and stockholder wealth. J. Financ. Econ. 1983, 11, 329-360. [CrossRef]

6. Zhang, Y.; Rajagopalan, N. Once an outsider, always an outsider? CEO origin, strategic change and firm performance. Strat. Manag. J. 2010, 31, 334-346. [CrossRef]

7. Finkelstein, S. Power in top management teams: Dimensions, measurement and validation. Acad. Manag. J. 1992, 35, 505-538. [CrossRef]

8. Finkelstein, S.; Hambrick, D.C. Top-management-team tenure and organizational outcomes: The moderating role of managerial discretion. Adm. Sci. Q. 1990, 35, 484-503. [CrossRef]

9. Goodstein, J.; Boeker, W. Turbulence at the top: A new perspective on governance structure changes and strategic change. Acad. Manag. J. 1991, 34, 306-330. [CrossRef]

10. Meyer, A.; Brooks, G.; Goes, J. Environmental joist and industry revolutions: Organizational responses to discontinuous change. Strat. Manag. J. 1990, 11, 93-110.

11. Kelly, P.; Amburgey, T. Organizational inertia and momentum: A dynamic model of strategic change. Acad. Manag. J. 1991, 34, 591-612. [CrossRef]

12. Haveman, H.A. Between a rock and a hard place: Organizational change and performance under conditions of fundamental environmental transformation. Adm. Sci. Q. 1992, 37, 48-75. [CrossRef]

13. Fox-Woldgramm, S.; Boal, K.; Hunt, J. Organizational adaptation to institutional change: A comparative study of first-order change in prospector and defender banks. Adm. Sci. Q. 1998, 43, 87-126. [CrossRef]

14. Wisersema, M.F.; Bantel, K.A. Top management team demography and corporate strategic change. Acad. Manag. J. 1992, 35, 91-121. [CrossRef] 
15. Boeker, W. Strategic change: The influence of managerial characteristics and organizational growth. Acad. Manag. J. 1997, 40, 152-170. [CrossRef]

16. Haynes, K.T.; Hillman, A. The effect of board capital and CEO power on strategic change. Strat. Manag. J. 2010, 31, 1145-1163. [CrossRef]

17. Quigley, T.J.; Hambrick, D.C. When the former CEO stays on as board chair: Effects on successor discretion, strategic change, and performance. Strat. Manag. J. 2012, 33, 834-859. [CrossRef]

18. Bebchuk, L.; Cohen, A.; Ferrell, A. What matters in corporate governance? Rev. Financ. Stud. 2009, 22, 783-827. [CrossRef]

19. Ahn, S.; Shrestha, K. The differential effects of classified boards on firm value. J. Bank. Financ. 2013, 37, 3993-4013. [CrossRef]

20. Danielson, M.G.; Karpoff, J.M. Do pills poison operating performance? J. Corp. Financ. 2006, 12, 536-559. [CrossRef]

21. Duru, A.; Wang, D.; Zhao, Y. Staggered boards, corporate opacity and firm value. J. Bank. Financ. 2013, 37, 341-360. [CrossRef]

22. Heron, R.A.; Lie, E. On the use of poison pills and defensive payouts by takeover targets. J. Bus. 2006, 79, 1783-1807. [CrossRef]

23. Bates, T.W.; Becher, D.A.; Lemmon, M.L. Board classification and managerial entrenchment: Evidence from the market for corporate control. J. Financ. Econ. 2008, 87, 656-677. [CrossRef]

24. Chen, Y.; Li, W.; Lin, K.J. Cumulative voting: Investor protection or antitakeover? Evidence from family firms in China. Corp. Gov. Int. Rev. 2015, 23, 234-248. [CrossRef]

25. Bebchuk, L.A.; Coates, I.J.C.; Subramanian, G. The powerful antitakeover force of staggered boards: Theory, evidence and policy. Stanford Law Rev. 2002, 54, 887-951. [CrossRef]

26. Vollman, T. The Transformation Imperative; Harvard Business School Press: Boston, MA, USA, 1996.

27. Kahneman, D.; Tversky, A. Prospect theory: An analysis of decision making under risk. Econometrica 1979, 47, 263-291. [CrossRef]

28. Sliwka, D. Managerial turnover and strategic change. Manag. Sci. 2007, 53, 1675-1687. [CrossRef]

29. Li, W. Corporate Governance in China: Research and Evaluation; John Wiley \& Sons (Asia) Pte. Ltd.: Singapore, 2008.

30. Fan, J.P.H.; Wong, T.J.; Zhang, T. Institutions and organizational structure: The case of state-owned corporate pyramids. J. Law Econ. Organ. 2013, 29, 1217-1252. [CrossRef]

31. Thompson, J. Organizations in Action: Social Science Bases of Administrative Theory; McGraw-Hill: New York, NY, USA, 1967.

32. Tan, J.J.; Litschert, R.J. Environment-strategy relationship and its performance implications: An empirical study of the Chinese electronics industry. Strat. Manag. J. 1994, 15, 1-20. [CrossRef]

33. Tan, J.J.; Tan, D. Environment-strategy co-evolution and co-alignment: A staged model of Chinese SOEs under transition. Strat. Manag. J. 2005, 26, 141-157. [CrossRef]

34. York, J.; Venkataraman, S. The entrepreneur-environment nexus: Uncertainty, innovation and allocation. J. Bus. Ventur. 2013, 41, 46-67. [CrossRef]

35. Lopes, L.L. Between hope and fear: The psychology of risk. Adv. Exp. Soc. Psychol. 1986, 20, $255-295$.

36. Dess, G.G.; Beard, D.W. Dimensions of Organizational Task Environments. Adm. Sci. Q. 1984, $29,52-73$. [CrossRef]

37. Tsai, S.B. Using the DEMATEL model to explore the job satisfaction of research and development professionals in china's photovoltaic cell industry. Renew. Sustain. Energy Rev. 2018, 81, 62-68. [CrossRef]

38. Lee, Y.C.; Hsiao, Y.C.; Peng, C.F.; Tsai, S.B.; Wu, C.H.; Chen, Q. Using Mahalanobis-Taguchi system, logistic regression, and neural network method to evaluate purchasing audit quality. Proc. Inst. Mech. Eng. Part B 2015, 229, 3-12. [CrossRef]

39. Liu, B.; Li, T.; Tsai, S.B. Low carbon strategy analysis of competing supply chains with different power structures. Sustainability 2017, 9, 835. [CrossRef]

40. Huang, Z.; Nie, J.; Tsai, S.B. Dynamic Collection Strategy and Coordination of a Remanufacturing Closed-Loop Supply Chain under Uncertainty. Sustainability 2017, 9, 683. [CrossRef]

41. Qu, Q.; Tsai, S.B.; Tang, M.; Xu, C.; Dong, W. Marine ecological environment management based on ecological compensation mechanisms. Sustainability 2016, 8, 1267. [CrossRef]

42. Tsai, S.B.; Yu, J.; Ma, L.; Luo, F.; Zhou, J.; Chen, Q.; Xu, L. A study on solving the production process problems of the photovoltaic cell industry. Renew. Sustain. Energy Rev. 2018, 82, 3546-3553. [CrossRef] 
43. Chin, T.; Tsai, S.B.; Fang, K.; Zhu, W.; Yang, D.; Liu, R.H.; Tsuei, R.T.C. EO-Performance relationships in reverse internationalization by Chinese Global Startup OEMs: Social networks and strategic flexibility. PLoS ONE 2016, 11, e0162175. [CrossRef] [PubMed]

44. Lee, S.C.; Su, J.M.; Tsai, S.B.; Lu, T.L.; Dong, W. A comprehensive survey of government auditors' self-efficacy and professional Development for improving audit quality. SpringerPlus 2016, 5, 1263. [CrossRef] [PubMed]

45. Lee, Y.C.; Wang, Y.C.; Chien, C.H.; Wu, C.H.; Lu, S.C.; Tsai, S.B.; Dong, W. Applying revised gap analysis model in measuring hotel service quality. SpringerPlus 2016, 5, 1191. [CrossRef] [PubMed]

46. Tsai, S.B.; Zhou, J.; Gao, Y.; Wang, J.; Li, G.; Zheng, Y.; Ren, P.; Xu, W. Combining FMEA with DEMATEL Models to Solve Production Process Problems. PLoS ONE 2017, 12, e0183634. [CrossRef] [PubMed]

47. Liu, W.; Wei, Q.; Huang, S.Q.; Tsai, S.B. Doing Good Again? A Multilevel Institutional Perspective on Corporate Environmental Responsibility and Philanthropic Strategy. Int. J. Environ. Res. Public Health 2017, 14, 1283. [CrossRef] [PubMed]

48. Wang, J.; Yang, J.M.; Chen, Q.; Tsai, S.B. Collaborative Production Structure of Knowledge Sharing Behavior in Internet Communities. Mob. Inf. Syst. 2016. [CrossRef]

49. Du, P.; Xu, L.; Chen, Q.; Tsai, S.B. Pricing competition on innovative product between innovator and entrant imitator facing strategic customers. Int. J. Prod. Res. 2016, 1-19. [CrossRef]

50. Liu, W.; Shi, H.B.; Zhang, Z.; Tsai, S.B.; Zhai, Y.; Chen, Q.; Wang, J. The Development Evaluation of Economic Zones in China. Int. J. Environ. Res. Public Health 2018, 15, 56. [CrossRef] [PubMed]

51. Fan, J.P.H.; Wong, T.J. Corporate ownership structure and the informativeness of accounting earning in East Asia. J. Account. Econ. 2002, 33, 401-425. [CrossRef]

52. Issaka, A.; SenGupta, I. Analysis of variance based instruments for Ornstein-Uhlenbeck type models: Swap and price index. Ann. Financ. 2017, 13, 401-434. [CrossRef]

(C) 2018 by the authors. Licensee MDPI, Basel, Switzerland. This article is an open access article distributed under the terms and conditions of the Creative Commons Attribution (CC BY) license (http:/ / creativecommons.org/licenses/by/4.0/). 